\title{
FLORAL DIMORPHISM IN UTRICULARIA JANARTHANAMII
}

M.M. SARDESAI • Department of Botany • M.E.S.'s Abasaheb Garware College • Karve Road • Pune • Maharashtra-411004・India・ sardesaimm@yahoo.co.in

S.R. YADAV • Department of Botany - Shivaji University • Kolhapur • Maharashtra-416 004• India•

Keywords: observations: Utricularia janarthanamii, Field studies: flowering.

The majority of flowering plants produce chasmogamous flowers, which require external agencies like wind, water, or animals for pollination to set fruit. Cleistogamous flowers are reduced flowers that never open and thus show obligate autogamy. Cleistogamous flowers are not uncommon, but chiefly occur in allogamous species, frequently after the conventional allogamous flowers have failed to set seeds. The development of cleistogamous flowers ensures seed is set in the absence of outcrossed seed, but may also produce less-fit offspring. In some plants only cleistogamous flowers are produced, which do not require external agencies for pollination to set fruit. Anderson (1980) reported a bizarre and intriguing way in which these flowers achieve self-fertilization.

Some plants produce both minute cleistogamous flowers and showy chasmogamic flowers on the same plant. Floral dimorphism is well known in many families such as Commelinaceae, Rubiaceae (Maheshwari \& Maheshwari 1955), Lentibulariaceae (Taylor 1989) and Malpighiaceae (Koul 2001). Normally chasmogamous and cleistogamous flowers are produced on aerial parts of the plant. However, in some plants chasmogamous flowers are produced above the ground and cleistogamous flowers below the ground (Uphof 1938; Camp \& Gilly 1943; Maheshwari 1960). Some members of Malpighiaceae, such as Aspicarpa, Camarea, Janusia and Gaudichaudia produce both cleistogamous and chasmogamic flowers on the same individuals, above the ground (Koul 2001). Cleistogamous and/or chasmogamous forms are found in some species of Utricularia (Taylor 1989).

The development from biotic to abiotic pollination and further (or directly) to autogamy may be considered as autonomous orthogenesis; but mostly it represents increasing adaptation to adverse conditions. Cleistogamy may either be seasonal, or a phenomenon induced by either inhospitable conditions or by the submersion of a normally emergent inflorescence (or part

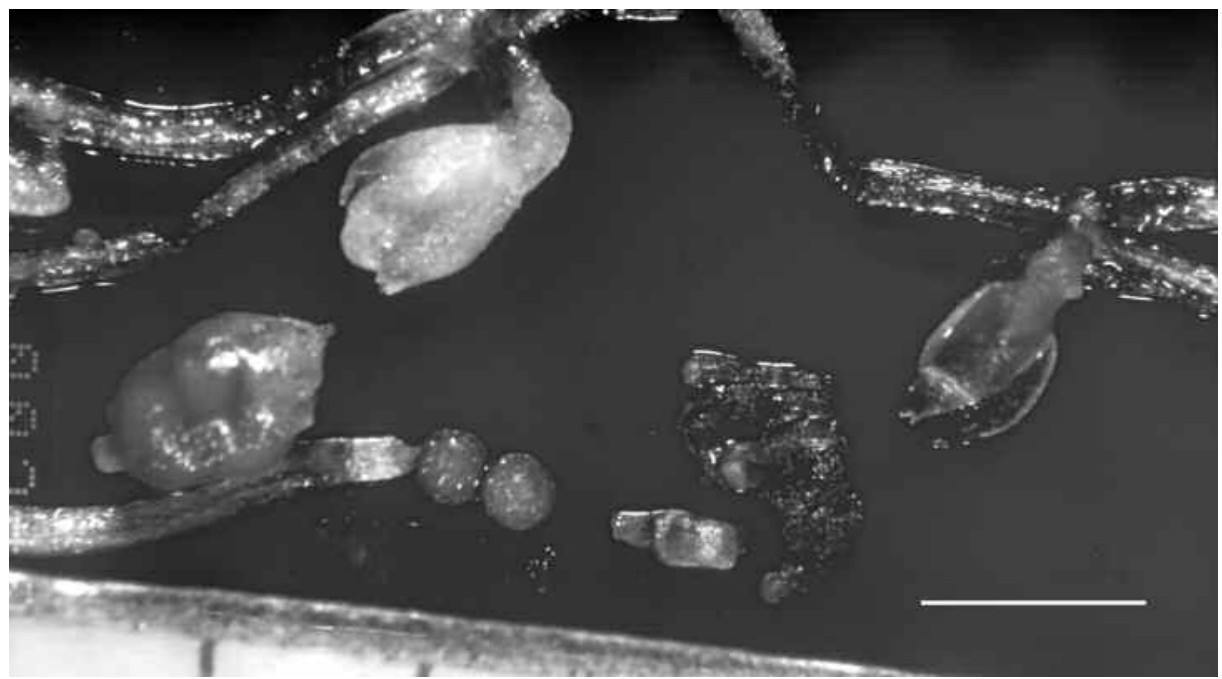

Figure 1: Utricularia janarthanamii, cleistogamous flower. Scale bar indicates $1 \mathrm{~mm}$. Photograph by S.R. Yadav. 
thereof). In short, chasmogamous flowers are produced in favourable season and cleistogamous flowers in unfavourable conditions. Such conditions may be represented by climates in which biotic vectors do not occur in sufficient numbers to ensure pollination, e.g. too dry or too cool climates.

A number of species produce flowers with a much reduced corolla that are self-pollinated without opening. These flowers are smaller than normal flowers and may be a seasonal phenomenon or induced, either by uncongenial conditions or by submersion of a normally emergent inflorescence or part thereof. Such types are described as pseudocleistogamy or ecological cleistogamy (Uphof 1938). In these species, the cleistogamy is conditional and primarily controlled by the environmental factors. Darwin $(1877)$ and Uphof $(1934,1938)$ are of the opinion that the cleistogamy is an adaptation for self pollination; these flowers represent retarded forms of chasmogamous type. In certain terrestrial species such as Utricularia subulata L., U. juncea Vahl, $U$. longeciliata A. DC., U. minutissima Vahl, U. pubescens Sm. and U. bisquamata Schrank, chasmogamous flowers are produced in the favourable season while cleistogamous flowers tend to be produced in the autumn.

However Burck (1906) considered that cleistogamy is controlled genetically and suggested that in many species of angiosperms such a condition might have been originated by mutation. This view is further supported by Weatherwax (1929) and Uphof (1934). In certain aquatic species like Utricularia benjaminiana Oliver, U. breviscapa Wright ex Griseb., U. trichophylla Spruce ex Oliver, $U$. dimorphantha Makino, and $U$. hydrocarpa Vahl, the cleistogamous flowers are at the base of chasmogamic inflorescences (Taylor 1989). However sometimes inflorescences are dimorphic (i.e., chasmogamous as well as cleistogamous), as in Utricularia geminiscapa Benj. and U. trichophylla Spruce ex Oliver. In these aquatic species cleistogamous inflorescences bear one or very rarely two flowers. Cleistogamous inflorescences are practically without peduncles.

\begin{tabular}{|c|c|c|}
\hline & Chasmogamous flowers & Cleistogamous flowers \\
\hline Flowers & Racemose, long peduncle & Solitary, reduced peduncle \\
\hline Bracts & 1.4-1.5 mm long & $0.25-0.30 \mathrm{~mm}$ long \\
\hline Pedicels & 4-8 $\mathrm{mm}$ long & Almost absent \\
\hline Upper calyx lobes & $\begin{array}{l}1.8-2 \times 1-1.2 \mathrm{~mm} ; \\
1.9-2.2 \times 1.2-1.4 \mathrm{~mm} \text { in fruit }\end{array}$ & $\begin{array}{l}0.55-0.6 \times 0.4-0.5 \mathrm{~mm} ; \\
0.8-0.9 \times 0.6-0.7 \mathrm{~mm} \text { in fruit }\end{array}$ \\
\hline Lower calyx lobes & $\begin{array}{l}2-2.2 \times 1.2-1.3 \mathrm{~mm} ; \\
2.5-2.7 \times 1.2-1.4 \mathrm{~mm} \text { in fruit }\end{array}$ & $\begin{array}{l}0.6-0.7 \times 0.4-0.45 \mathrm{~mm} ; \\
0.9-1.1 \times 0.5-0.6 \mathrm{~mm} \text { in fruit }\end{array}$ \\
\hline Corolla & Blue to pink & Hyaline \\
\hline Upper corolla lip & $\begin{array}{l}3.2-3.3 \times 1-1.1 \mathrm{~mm} \text {; linear- } \\
\text { oblong, crested at centre, round- } \\
\text { ed or notched at apex }\end{array}$ & $\begin{array}{l}1.2-1.4 \times 0.6-0.8 \mathrm{~mm} \text {; shortly } 2- \\
\text { lobed, overlapping lower lip }\end{array}$ \\
\hline Lower corolla lip & $\begin{array}{l}3-3.2 \times 3.8-4.2 \mathrm{~mm} \text {, obovate, } \\
\text { hairy in throat, bigibbous at } \\
\text { base, rounded at apex }\end{array}$ & $\begin{array}{l}\text { Shallowly lobed, } 1.3-1.5 \times 1.5-2 \\
\text { mm, convolute }\end{array}$ \\
\hline Spur & $\begin{array}{l}2-5 \mathrm{~mm} \text { long, conical, descend- } \\
\text { ing, acute or 2-3 dentate at apex }\end{array}$ & Almost absent \\
\hline Stamens & $1-1.2 \mathrm{~mm}$ long. & $0.45-0.5 \mathrm{~mm}$ long \\
\hline Pistil & $0.9-1.1 \mathrm{~mm}$ long & $0.35-0.4 \mathrm{~mm}$ long \\
\hline Capsule & $1.8-2 \times 1.2-1.3 \mathrm{~mm}$ & Capsules: $1.25-1.5 \times 0.75-0.8 \mathrm{~mm}$ \\
\hline
\end{tabular}


During our survey on flowering plants of Maharashtra State, about 23 species of Utricularia were collected (Sardesai et al. 2001). On critical analysis, three species turned out to be novelties (Yadav et al. 2000, 2005). Of these, U. janarthanamii Yadav, Sardesai \& Gaikwad exhibits two types of flowers in the same individual. This species grows at an altitude of about 500-600 $\mathrm{m}$ on wet grounds, marshy rice fields, and wet grasslands and is known only from the foothills of Western Ghats of Maharashtra. The species flowers from July to April. The rainy season is favourable for vigorous growth. The cleistogamous nature of flowers along with chasmogamous flowers occurs throughout the range of its distribution. The overall dimensions of cleistogamous flowers are much smaller than those of chasmogamous flowers.

\section{References:}

Anderson, W.R. 1980. Cryptic-self fertilisation in the Malpighiaceae. Science. 207: 892-893.

Burck, W. 1906. Die Mutation als Urasche der Kleistogamie. Rec. Trav. bot. neerl. 2:37-164.

Camp, W.H. and Gilly, C.L. 1943. The structure and origin of species. Brittonia 4: 254-258.

Darwin, C. 1877. The different forms of flowers on same species. London.

Koul, A.K. 2001. Double fertilisation-changing frontiers. Phytomorphology. Golden Jubilee Issue. 237-250.

Maheshwari, P., and Maheshwari, J.K. 1955. Floral dimorphism in Commelina forskalaei Vahl and C. benghalensis L. Phytomorphology 5: 413-422.

Maheshwari, J.K. 1960. Cleistogamy in angiosperms. Proceeding of the Summer School of Botany (Darjeeling) New Delhi.

Sardesai, M.M., Bhuskute, S.M., and Yadav, S.R. 2001. Lentibulariaceae in Maharashtra. J. Econ. Tax. Bot. 25 (3): 687-702.

Taylor, P. 1989. The genus Utricularia-a taxonomic monograph. Kew Bull. Add. Ser. 14: 1-724

Uphof, J.C. Th. 1934. Verleichende blutenmorphologische und blutenbiologische studien an Commelina virginica L. Ber. Dtsch. Bot. Ges. 52: 173-180.

Uphof, J.C. Th. 1938. Cleistogamous flowers. Bot. Rev. 4: 21-49.

Weatherwax, P. 1929. Cleistogamy in Poa champaniana Torreya 29: 123-124.

Yadav, S.R., Sardesai, M.M., and Gaikwad, S.P. 2000. Two new species of Utricularia L. (Lentibulariaceae) from Peninsular India. Rheedea. 10 (2): 107-112.

Yadav, S.R., Sardesai, M.M., and Gaikwad, S.P. 2005. A new species of Utricularia (Lentibulariaceae) from Western Ghats of Maharashtra, India. Rheedea. 15 (1): 71-73.

\section{7th Conference of the ICPS in 2008!}

It gives me great pleasure to announce that the 2008 International Carnivorous Plant Society Conference will be held in Sydney, Australia. The venue chosen is the Royal Botanic Gardens, in the heart of the city, close to many facilities. Since this is the first time this biennial conference has been held in the Southern Hemisphere it was deemed appropriate for it to be held at a time when the carnivorous plants across most of southern Australia would be at their best, and so the conference will be held from the $25 \mathrm{nd}$ to the 28th of September. The conference will include a number of lectures and demonstrations, and there will be some optional field trips to the Blue Mountains and Mt Tomah Botanic Gardens, both within 3 hours drive from Sydney. Provisions are also being made for a field trip to see Cephalotus, pygmy sundews and tuberous sundews in South Western Australia for conference attendees able to make it to this part of the country during their stay down under. Stay tuned for further details, and please mark the dates in your diaries; we'd love to see you in Sydney in 2008.

Greg Bourke 


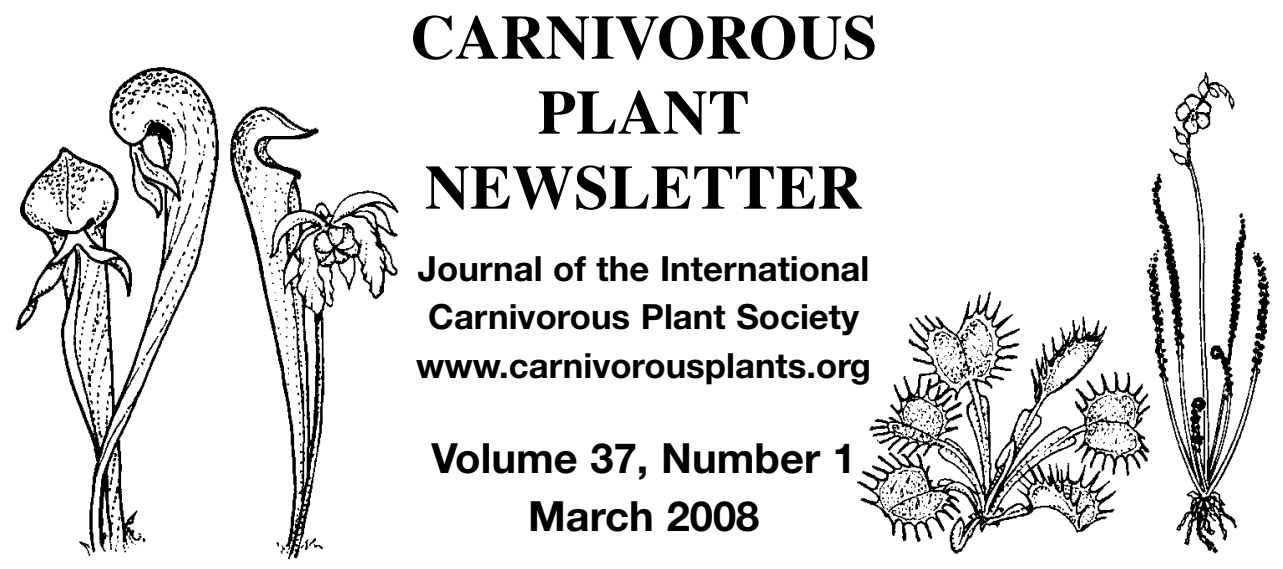

Front Cover: Utricularia janarthanamii, chasmogamous flower. Photograph by S. Ingalhalikar. Article on page 12.

Back Cover: The Alarm River site for $U$. australis in Lar National Park. Inset: $U$. australis in flower. Photograph by A. Naqinezhad. Article on page 4.

Carnivorous Plant Newsletter is dedicated to spreading knowledge and news related to carnivorous plants. Reader contributions are essential for this mission to be successful. Do not hesitate to contact the editors with information about your plants, conservation projects, field trips, or noteworthy events. Contributors should review the "Instructions to Authors" printed in the March issue of each year. Advertisers should contact the editors. Views expressed in this publication are those of the authors, not the editorial staff.

All correspondence regarding dues, address changes and missing issues should be sent to the Membership Coordinator at the ICPS. Do not send such correspondence to the editors. Checks for subscriptions and back issues should be made to the ICPS in US funds. Dues for 2008 are \$25.

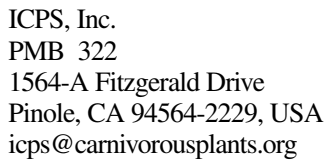

President_ Doug Darnowski, doug@carnivorousplants.org

Vice President Cindy Slezak, email: cindy@carnivorousplants.org

Secretary, Seed Bank John Brittnacher, email: john@ carnivorousplants.org, seedbank listed in this issue.

Treasurer Richard Myers, email: richard@carnivorousplants.org

Board Member Chris Teichreb, email: chris@carnivorousplants.org

Board Member Bob Ziemer, bob@carnivorousplants.org

Editors:

Barry A. Rice, P.O. Box 72741, Davis, CA 95617, USA, email: barry@ carnivorousplants.org

Jan Schlauer, Zwischenstr. 11, D-60594 Frankfurt, Germany, email: jan@ carnivorousplants.org

Page Layout: Steve Baker, email: steve@ carnivorousplants.org

Date of effective publication of the December 2007 issue of Carnivorous Plant Newsletter: 22 December 2007.

The ICPS is the International Cultivar Registration Authority (ICRA) for cultivated carnivorous plants according to The International Code For The Nomenclature of Cultivated Plants. Send relevant correspondence to the ICPS, Inc.

PUBLISHER: ICPS, Inc., Pinole, California. Published quarterly with one volume annually. Desktop Publishing: Steve Baker, 5612 Creek Point Drive, Hickory, NC 28601. Printer: Kandid Litho. Logo and masthead art: Paul Milauskas. Dues: \$25.00 annually. @ 2008 Carnivorous Plant Newsletter. All rights reserved. ISSN \#0190-9215. 


\section{CARNIVOROUS PLANT}

\section{NEWSLETTER}

Journal of the International Carnivorous Plant Society Volume 37 , No. 1 March 2008

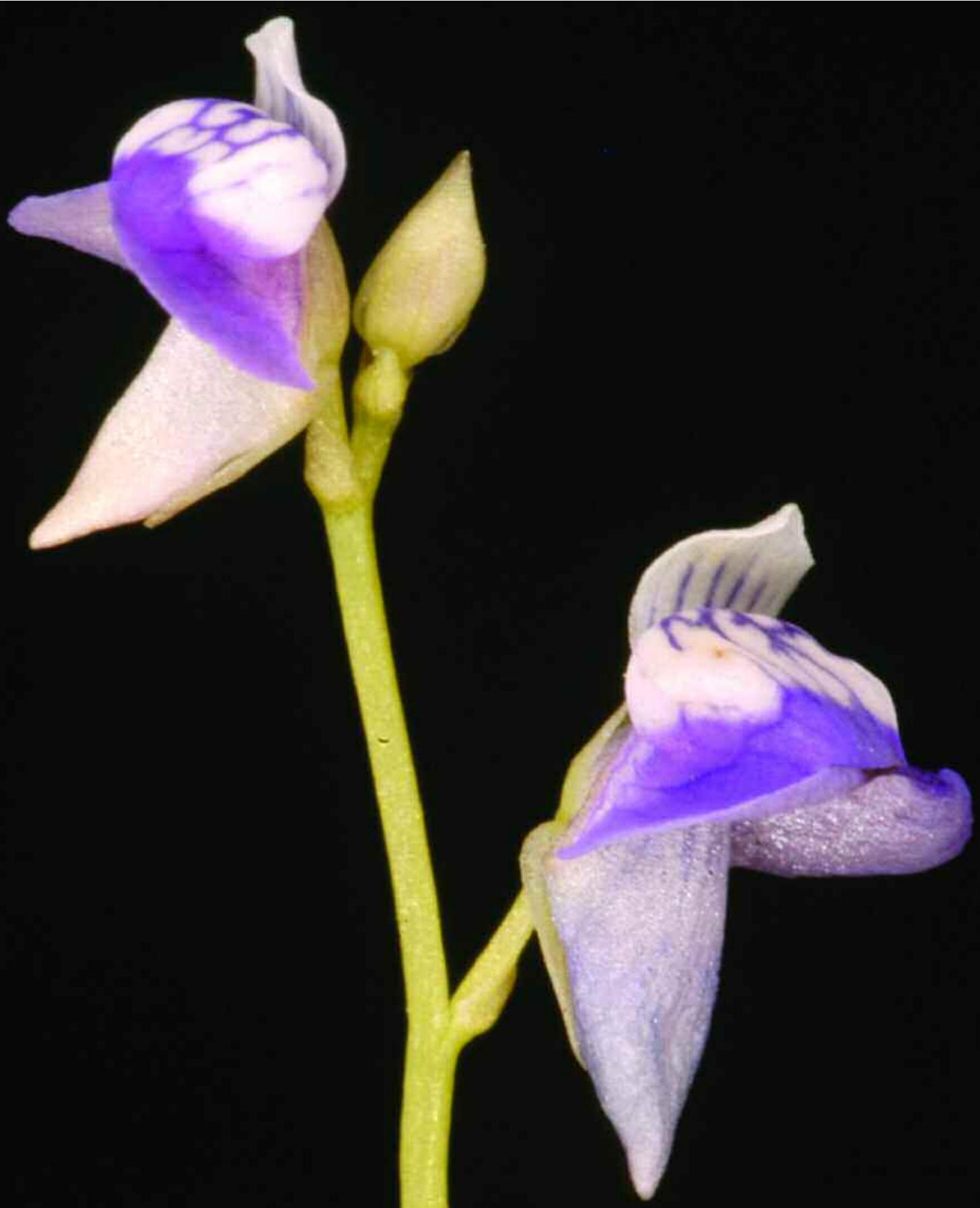

